\title{
STRATEGI PEMBERDAYAAN PEREMPUAN DI DINAS PEMBERDAYAAN PEREMPUAN DAN PERLINDUNGAN ANAK KOTA SUNGAI PENUH
}

\author{
NANIK MANDASARI, EKA SEPTIANI
}

STIA NUSANTARA SAKTI SUNGAI PENUH

\author{
Email: \\ mandasarinanik@gmail.com \\ ekayani1809@gmail.com
}

\begin{abstract}
The women's empowerment strategy is one of the government's programs as an effort to solve the problems faced by the community so that it can fulfill the desires and needs of the community towards a better and more advanced direction. The purpose of this study was to determine the process of the Women's Empowerment Strategy in the Office of Women's Empowerment and Child Protection in Sungai Penuh City and the factors that influence it. The type of research used is descriptive qualitative. The data used there are two types of data, namely primary data and secondary data, the data was analyzed descriptively qualitatively which was collected by the author and then displayed in the form of sentences according to interviews from 10 informants. The research uses a phenomenological type. Data collection techniques used instruments in the form of observations, interviews, literature studies and documents. The results showed that there were four related issues, namely: women's participation was good, the programs implemented were not optimal, women's awareness was still lacking, and socialization was not evenly distributed throughout society. The hope in the future is that through the strategy implemented by the Office of Women's Empowerment and Child Protection in Sungai Penuh City regarding the strategy of empowering women, it can be carried out in stages and continuously and guidance for women must continue to be improved.

Keywords: Strategy, Women Empowerment
\end{abstract}

\begin{abstract}
ABSTRAK
Strategi pemberdayaan perempuan merupakan salah satu program pemerintah sebagai upaya untuk memecahkan masalah yang dihadapi masyarakat sehingga dapatmemenuhi keinginan dan kebutuhan masyarakat kearah yang lebih baik dan lebih maju. Tujuan dari penelitian adalah ini untuk mengetahui proses Strategi Pemberdayaan Perempuan di Dinas Pemberdayaan Perempuan dan Perlindungan Anak Kota Sungai Penuh dan faktor-faktor yang mempengaruhinya. Jenis penelitian yang digunakan adalah deskriptif kualitatif. Data yang digunakan ada dua jenis data yaitu data primer dan data sekunder, data tersebut di analisis secara deskriptif kualitatif yang berhasil dikumpulkan penulisdan selanjutnya ditampilkan
\end{abstract}


dalam bentuk kalimat sesuai dengan wawancara dari 10 informan. Penelitian menggunakan tipe fenomenologis. Teknik pengumpulan data menggunakan instrumen berupa observasi, wawancara, studi kepustakaan dan dokumen. Hasil penelitian menunjukkan bahwa ada empat yang terkait dalam hal ini yaitu: partisipasi perempuan sudah baik, program yang dilaksanakan belum maksimal, kesadaran perempuan masih kurang, sosialisasi yang tidak merata diseluruh lapisan masyarakat. Harapan kedepan bahwa melalui strategi yang dilaksanakan oleh Dinas Pemberdayaan Perempuan dan Perlindungan Anak Kota Sungai Penuh mengenai strategi pemberdayaan perempuan dapat di laksanakan dilakukan secara bertahap dan bekesinambungan serta pembinaan terhadap perempuan harus terus di tingkatkan.

Kata Kunci: Strategi, Pemberdayaan Perempuan

\section{Latar Belakang Masalah}

\section{PENDAHULUAN}

Indikasi penelitian dalam pemberdayaan perempuan yaitu masih banyak terjadi kekerasan perempuan yang merugikan kaum perempuan, dan ada beberapa masyarakat khususnya di Kota Sungai Penuh yang kurang memahami tentang Pemberdayaan Perempuan sehingga pelaksanaannya kurang efektif dan maksimal, bagaimana masyarakat merasa pemberdayaan bukan sesuatu hal yang penting sehingga kemauan untuk terlibat tidak ada. Dengan adanya masalah tersebut tentu membawa pengaruh terhadap pelaksanaan pemberdayaan perempuan di Kota Sungai Penuh. Oleh sebab itu pemerintah perlu memikirkan hal ini secara serius serta upaya melakukan pengoptimalan peningkatan strategi pemberdayaan perempuan, sehingga perempuan dapat diberdayakan dengan maksimal, untuk meningkatkanstrategi pemberdayaan perempuan di Daerah secara khusus dan Kota Sungai Penuh.

Secara umum sebagaimana pemberdayaan erat kaitannya dengan keberhasilan pembangunan di suatu daerah. Isbandi Adi, (2013) Pemberdayaan perempuan dalam konteks sosial merupakan upaya proses pembangunan dimana perempuan harus selalu berinisiatif untuk melakukan proses kegiatan sosial yang dapat memperbaiki situasi dan kondisi dalam suatu masyarakat sehingga dapat memeratakan dan meningkatkanpembangunan serta kesejahteraan masyarakat di daerahnya.

Beberapa faktor yang menyebabkan pemberdayaan perempuan menjadi hal yang sangat penting yaitu :

1. Pembangunan dengan perspektif partikal mengakibatkan perempuan menjadi tidak berdaya karena tidak dapat mengekspresikan kemampuan/bakat yang dimilikinya.

2. Tingkat pendidikan terhadap perempuan cenderung lebih rendah ketimbang laki-laki dan hak reproduksi yang cenderung dipaksakan.

3. Ketertinggalan peran perempuan didalam bidang pemerintahan dan politik.

Agar semuanya berjalan dengan seimbang maka diperlukannya upaya untuk melakukan suatu pemberdayaan terhadap perempuan agar mereka mempunyai akses dan kontrol terhadap semua aspek pembangunan yang tujuan akhirnya adalah 
kesetaraan antara laki-laki dan perempuan dan peningkatan pemberdayaan di suatu Daerah. Selain pemahaman perempuan tentang peraturan daerah pemahaman perempuan tentang pemberdayaan perempuan masih sangat kurang sehingga menjadi faktor penghambat keberhasilan perempuan dalam pembangunan. Kekerasan dalam berbagai bentuk baik fisik maupun psikis sudah diatur dalam undang-undang nomor 23 tahun 2004 tentang penghapusan Kekerasan Dalam Rumah Tangga (KDRT). Kemudian juga tahun 2019 Pemprov Jambi juga sudah mengeluarkan peraturan daerah nomor 7 tahun 2019 tentang penyelenggaraan perlindungan perempuan dan anak Berbagai upaya untuk meningkatkan peran perempuan pada posisi strategis dalam rangka memecahkan berbagai masalah dan memberikan perlindungan bagi anak terus dikembangkan. Dalam mencapai upaya ini, Dinas PemberdayaanPerempuan dan Perlindungan Anak di wilayah Provinsi Jambi diharapkan dapat memberikan peran secara optimal. Namun dalam menjalankan tugas dan fungsinya Dinas Pemberdayaan Perempuan dan Perlindungan Anak Kota Sungai Penuh harus fokus melakukan kegiatan untuk menjawab persoalan dan masalah-masalah yang dihadapi oleh perempuan dan anak di Kota Sungai Penuh sebagai berikut :

1. Masih rendahnya kualitas hidup dan peran perempuan.

2. Masih tingginya tindak kekerasan terhadap perempuan dan anak.

3. Masih rendahnya kesejahteraan dan perlindungan anak.

4. Masih terdapat peraturan dan kebijakan yang bias gender, diskriminatif terhadap perempuan, dan belum peduli anak.

5. Masih lemahnya kelembagaan dan jaringan pengarusutamaan gender dan anak, termasuk ketersediaan data dan rendahnya partisipasi masyarakat.

Pemerintah telah melaksanakan berbagai bentuk kebijakan untuk memberdayakan salah satunya adalah Pengarusutamakan Gender dalam Pembangunan Daerah Di Kota Sungai Penuh, yang tertuang kedalam peraturan Walikota Sungai Penuh Nomor 14 Tahun 2020. Dalam rangka pelaksanaan strategi pemberdayaan perempuan salah satu indikator untuk mengukur tingkat keberhasilannya dengan melihat perbandingan yang terjadi setiap tahunnya, 20142019 ada 1 kota kabupaten, yang belum ada keterwakilan perempuan dan posisi Provinsi Jambi tidak bisa mencapai $30 \%$.

Strategi pemberdayaan perempuan berpijak pada filosofi pembangunan yang menjadikan kaum perempuan sebagai mitra sejajar dengan kaum laki-laki. Berdasarkan dari uraian di atas penulis berkeinginan untuk melakukam penelitian dengan judul "Strategi Pemberdayaan Perempuan di Dinas Pemberdayaan Perempuan dan Perlindungan Anak Kota Sungai Penuh"

Adapun rumusan masalah yang akan dikaji adalah:

1. Bagaimana strategi pemberdayaan perempuan di Dinas Pemberdayaan Perempuan dan Perlindungan Anak Anak Kota Sungai Penuh di tinjau dari bimbingan konseling, pemberdayaan kelompok, membentuk kelompok usaha, memotivasi perempuan, peningkatan kesadaran dan pelatihan kemampuan, pembangunan dan pengembangan jaringan ?

2. Apa faktor pendukung dan penghambat pemberdayaan perempuan di Dinas Pemberdayaan Perempuan dan Perlindungan Anak Kota Sungai Penuh? 


\section{METODE PENELITIAN}

Penelitian tentang Strategi Pemberdayaan perempuan di Dinas Pemberdayaan Perempuan dan Perlindungan Anak Anak Kota Sungai Penuh ini menggunakan pendekatan penelitian deskriptif dengan pendekatan kualitatif. Pendekatan kualitatif adalah prosedur penelitian yang menghasilkan data deskriptif berupa kata-kata tertulis atau lisan dari orang-orang dan prilaku yang dapat diamati (Moleong, 2002:3).

Metode penelitian kualitatif membuka ruang yang cukup bagi dialog ilmu dalam konteks yang berbeda, terutama apabila ia dipahami secara mendalam dan "tepat". Penelitian kualitatif dapat mengeksplorasi sikap, prilaku, dan pengalaman responden melalui metode interview dan fokus group. Pendekatan ini diharapkan mampu menjaring realita dilapangan dengan mengumpulkan data secara langsung dilapangan melalui wawancara, dokumentasi dan observasi.

Dalam penelitian ini peneliti menggunakan informan kunci (key informan) dan informan biasa. Informan kunci merupakan informan yang mengetahui secara mendalam permasalahan yang sedang diteliti, sedangkan informan biasa merupakan informan yang ditentukan dengan dasar pertimbangan mengetahui dan berhubungan dengan permasalahan. Dalam hal ini penulis menggunakan metode purposive sampling. Yaitu pengambilan sampel yang di sesuaikan dengan tujuan dan syarat tertentu yang ditetapkan berdasarkan tujuan dan masalah penelitian.(Nawawi, 1987:157). Dalam penelitian ini peneliti telah menemukan 8 orang informan.

\section{Teknik Dan Alat Pengumpulan Data}
a. Observasi
b. Wawancara
c. Dokumentasi

\section{Analisis Data}

Di dalam melakukan analisis data penelitian mengacu kepada beberapa tahapan yaitu:

1. Pengumpulan informasi melalui wawancara.

2. Reduksi data (data reduction)

3. Penyajian data(data display)

4. Kesimpulan atau verifikasi (conslusion) 


\section{Bagan Kerangka Pikir}

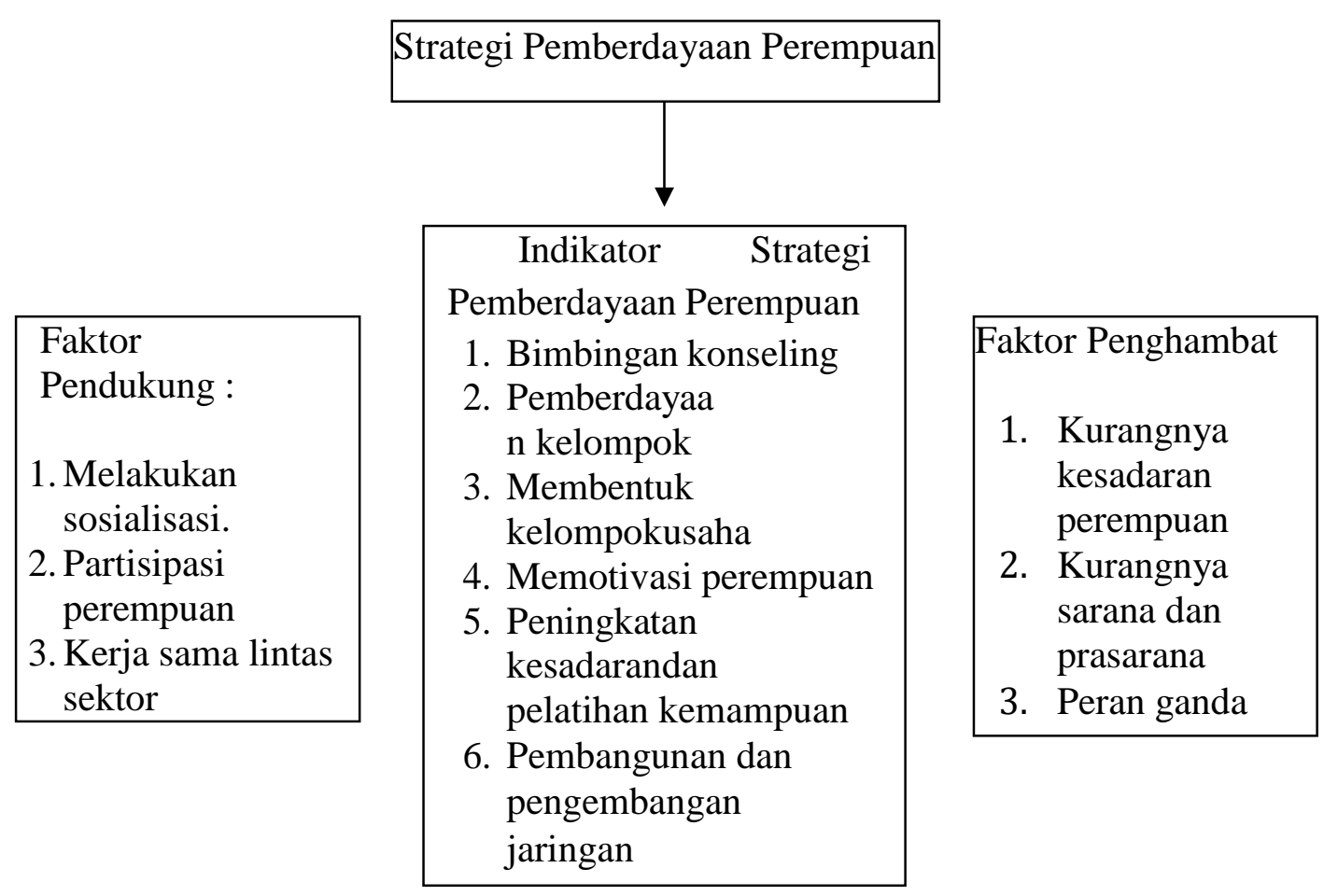
Peningkatan pemberdayaan perempuan di
Dinas Pemberdayaan Perempuan dan Perlindungan Anak Kota Sungai Penuh

\section{HASIL DAN PEMBAHASAN}

\section{A. Masalah Yang Menimpa Kaum Perempuan}

Kekerasan terhadap perempuan" dalam Undang-undang Nomor UU No 23 Tahun 2004 didefinisikan sebagai setiap perbuatan terhadap seseorang terutama perempuan, yang berakibat timbulnya kesengsaraan atau penderitaan secara fisik, seksual, psikologis, dan/atau penelantaran rumah tangga termasuk ancaman untuk melakukan perbuatan, pemaksaan, atau perampasan kemerdekaan secara melawan hukum dalam lingkup rumah tangga.

Kekerasan dalam rumah tangga adalah setiap perbuatan terhadap seseorang terutama perempuan, yang berakibat timbulnya kesengsaraan atau penderitaan secara fisik, seksual, psikologis, dan atau penelantaran rumah tangga termasuk ancaman untuk melakukan perbuatan, pemaksaan, atau perampasan kemerdekaan secara melawan hukum dalam lingkup rumah tangga.

Seringkali kekerasan pada perempuan terjadi karena adanya relasi atau hubungan yang tidak seimbang antara perempaun dan laki- laki hal ini disebut ketimpangan atau ketidakadilan gender. Ketimpangan gender adalah perbedaan peran dan hak perempuan dan laki-laki di masyarakat yang menempatkan 
perempuan dalamstatus lebih rendah dari laki-laki. "Hak istimewa" yang dimiliki laki-laki ini seolah- olah menjadikan perempuan sebagai "barang" milik laki-laki yang berhak untukdiperlakukan semena-mena, termasuk dengan cara kekerasan

Upaya untuk menghilangkan kekerasan terhadap perempuan di Kota Sungai Penuh adalah salah satu strategi yang dilakukan oleh Dinas pemerdayaan peremuan dan perlindungan anak di Kota Sungai Penuh. Jumlah kasus kekerasan terhadap perempuan dan anak di Provinsi Jambi Januari 2020 sangat tinggi. Berdasarkan data sistem informasi online (Simfoni) milik Kementrian Pemberdayaan Perempuan dan Perlindungan Anak RI telah terjadi 14 kasus kekerasan terhadap perempuan dan anak selama 1 bulan, 14 kasus tersebut terdiri dari kekerasan terhadap anak sebanyak 8 orang dan kekerasan terhadap perempuan sebanyak 4 orang. Adapun jenis kekerasan yang dialami adalah psikis anak sebanyak 8 orang dan psikis perempuan 4 orang dan laki-laki dewasa 2 orang. Sedangkan kekerasan seksual kepada anak sebanyak 6 orang. Jumlah kasus ini bisa lebih tinggi fakta dilapangan. Sebab tidak semua orang ingin untuk melaporkan bila mengalami kekerasan karena dianggap sebagai aib keluarga. Sementara itu, jumlah kekerasan yang terjadi sepanjang tahun 2019 sebanyak 123 kasus. Kekerasan itu di kelompokkan dalam kekerasan fisik anak 9 orang, perempuan 18 orang, kekerasan psikis anak 62 orang, perempuan 44 orang dan laki-laki dewasa 6 orang. Selanjutanya kekerasan seksual anak 40 orang, perempuan 2 orang kemudian penelantaran anak 4 orang dan perempuan 10 orang. Adapun yang menghuni rumah perlindungan anak sebanyak 1 orang perempuan korban pemerkosaan, 5 korban anak kekerasan psikis, 5 orang perempuan KDRT dan 1 orang anak kekerasan seksual.

Dari hasil wawancara peneliti dengan narasumber staf yang menangani Pemberdayaan Perempuan dapat disimpulkan bahwa kekerasan terhadap perempuan sering terjadi kepada masayarakat (perempuan) menengah kebawah (miskin) banyaknya jumlah kasus kekerasan menimpa perempuan menjadi tugas besar Dinas Pemberdayaan Perempuan untuk memberdayakan perempuan sehingga dapat menghilangkan kekerasan terhadap perempuan, sebagaimana pelaksana adalah penentu keberhasilan untuk membawa perempuan keluar dari kekerasan yang banyak menimpa kaum perempuan sehingga kedepannya perempuan mendapatkan perlakuan yang baik, adil dan tanpa tekanan di masyarakat. Dalam upaya pengendalian jumlah kasus yangbanyak menimpa kaum perempuan melalui pelaksanaan program kerja oleh dinas pemberdayaan perempuan maka perlu adanya proses penyelenggaraan yang sistematis yang menjadi kegiatan prioritas dilapangan guna menunjang keberhasilan plaksanaan strategi pemberdayaaan perempuan secara menyeluruh.

Dari uraian di atas menunjukkan bahwa marakanya terjadi kasus kekerasan dan banyak menimpa kaum perempuan menjadi tugas semua kalangan masayarakat untuk turut serta melakukan kerja sama yang baik kepada semua pihak untuk memberi pengarahan yang positif kepada semua masyarakat bai laki-laki dan perempuan sehingga kasus-kasus yang sering menimpa kaum perempuan dapat di hilangkan.

\section{Bimbingan Konseling}

Gibson and Michell, (2010) Konseling merupakan profesi penolong 
adalahsuatu konsep yang melandasi fungsi serta peran konselor di masyarakat. Profesi penolong adalah profesi yang setiap anggotanya dilatih khusus sehingga memiliki lisensi skill, dan pemahaman terhadap sesuatu sesuatu.

Proses perencanaan strategi agar tercapainya tujuan dengan baik maka harus ada bimbingan konseling tujuannya untuk menyadarkan perempuan agar dapat memahami kemampuan dan potensi dirinya.

Dari apa yang disampaikan oleh informan bahwa ada beberapa perempuan yang selama ini mengalami banyak masalah baik dalam lingkungan keluarga dan kelompok atau hubungan emosionalnya dengan kelompoknya mereka sering menceritakan keluhannya dan meminta saran kepada seksi perlindungan dan pemberdayaan perempuan di Dinas Pemberdayaan Perempuan, hal ini menjadi salah satu fungsi bagian seksi perlindungan Perempuan untuk memberikan masukanberupa sumbangan pemikiran baik dalam bentuk solusi atau saran. Peran Pemberdayaan perempuan di Kota Sungai Penuh sangat besar sebagai wadah menampung masalah yang dihadapi oleh perempuan untuk memberikan perhatian khusus kepada perempuan yang kurang aktif, atau yang banyak mengalami masalah dalam rumah tangganya kemudian membantu dan memberikan solusi terlepas dari pada itu perempuan dapat memahami apa yang ada pada diri mereka dan dapat bekerja sama dengan baik dalam lingkup kelompoknya maupun di masyarakat. Terlihat bahwa pelaksanaan dalam hal bimbingan konseling yang dilakukan di Kota Sungai Penuh belum terlalu optimal karena hanya dilakukan sesekali dan kurang efektif dan efisien hal itu juga menjadi salah satu pKota Sungai Penuh enghambat perempuan untuk lebih maju.

\section{Pemberdayaan kelompok}

Kelompok adalah sejumlah individu yang berkolaborasi, berkomunikasi satu sama lain melaksanakan kegiatan atau program dalam beberapa jangka waktu tertentu yang jumlahnya tidak terlalu banyak, sehingga hal tersebut memberika kesempatan bagi semua anggota untuk berkomunikasi secara langsung. Dari hasil wawancara dengan informan terlihat bahwa pemberdaayaan perempuan berjalan dengan baik ketika program kerja yang ada dapat berjalan sesuai dengan tujuan. berpartisipasimengembangkan usaha. Pemberdayaan kelompok bertujuan untuk memberdayakan perempuan dengan cara membekali perempuan dengan keterampilan, skill sehingga perempuan mempunyai peran akses dimasyarakat. Seperti yang disampaikan oleh informan bahwa sudah ada kelompok yang diberdayakan dan sudah terlihat hasilnya karena sudah dapat menghasilkan dan memenuhi kebutuhannya terlebih sudah dapat membuka lapangan pekerjaan hal ini erat kaitannya dengan strategi menimalisir terjadinya perceraian karena faktor ekonomi dan lain sebagainya. Terlihat juga bahwa Tp-Pkk sebagai wadah untuk membantu memberdayakan perempuan dan keluarga sudah banyak memberi sumbangsi pikiran dan tenaga untuk melibatkan dan mendorong untuk memberdayakan perempuan di Kota Sungai Penuh tujuannya adalah demi kesejahteraan keluarga dan perempuan. Sehingga melalui kegiatan yang dilakukan dapat mempengaruhi perempuan agar dapat lebih produktif dan berdaya.

Selain itu terlihat juga ada ketidak merataan keterlibatan perempuan di dalam proses yang berkaitan dengan keterlibatan mereka pada program-program kerja yang dilaksanakan hal itu kemudian menjadi penghambat bagi perempuan 
untuk berkembang sebagaimana yang yang dimaksudkan di atas ada ada keinginan terlibat akan tetapi sudah ada yang di tunjuk langsung dari kecamatan Sebagaimana keberhasilan suatu proses pemberdayaaan perempuan apabila semua perempuan dapat terlibat dan berdaya.

\section{Pemberdayaan Kelompok Usaha}

Pemberdayaan kelompok merupakan kegiatan yang mempertemukan orang- orang dengan tujuan yang sama untuk mengembangkan sesuatu yang sudah direncanakan sebelumnya. Salah satu indikator keberhasilan sebuah kelompok ketika semua elemen dalam suatu kelompok tersebut merasakan hasilnya. Untuk meningkatkan SDM pada kelompok usaha yang harus dilakuka adalah menyiapkan fasilitas dan melakukan sosialisasi guna untuk meningkatkan minat dan kemampuan dalam bidang usaha yang dilakukan. Muljana (1995) strategi dalam meningkatkan kegiatan program kelompok usaha.

1. Meningkatkan kemampuan organisasi dengan medorong agar perlengkapanberfungsi sepenuhnya.

2. Membina dan mengembangkan kemampuan teknis, keterampilan manajemen.

3. manajemen dan jiwa wirausaha para anggota pengurus, karyawan dan manajer.

4. Meningkatkan dn memperluas kegiatan penenerangan dan penyuluhan baik dikalangan internal maupun di masyarakat luas.

5. Membantu pembinaan kerja sama antar sesama antar wirausaha.

Sesuai dari apa yang disampaikan oleh salah satu informan bahwa dari program yang ada dimana dinas pemberdayaan perempuan sebagai wadah untuk memberdayakan perempuan di Kota Sungai Penuh sudah banyak melaksanakan tugasnya termasuk di dalamnya adalah memberikan pemahaman tentang cara mengelola usaha yang baik, orientasinya adalah keberhasilan usaha perempuan di Kota Sungai Penuh. Terlihat juga bahwa kesadaran perempuan di Kota Sungai Penuh tentangpengembangan usaha perempuan masih kurang dilihat dari tingkat partisipasi perempuan yang terbilang minim hal tersebut menjadi penghambat perempuan untuk lebih berkembang dan lebih produktif.

\section{Memotivasi Perempuan}

Motivasi adalah sebuah konsekuensi akbit dari sebuah hasil yang ingin capai atau diraih seseorang dan suatu perkiraan bahwa apa yang dilakukan mengarah pada hasil yang di inginkannya. Motivasi dapat diartikan sebagai suatu tujuan atau pendorong untuk mencapai hasil, dengan kata lain tujuan yang ingin dicapai sebenarnya menjadi daya penggerak utama bagi seseorang dalam berupaya dalam mendapatkan atau mencapai apa yang diinginkannya baik itu secara positif ataupun negatif. Sebagaimana menurut salah satu narasumber bahwa, terlihat bahwa perempuan di Kota Sungai Penuh pada dasarnya memiliki keahlian karena di bentuk dan didukung oleh alam disekitarnya sehingga memaksimalkan kemampuan yang dimiliki sebagaimana untuk tercapainya tujuan pembangunan tentu pemerintah dan masyarakat harus bekerja sama untuk meningkatkan semangat individu dalam mengelola Sumber daya Alam yang dimiliki dan selalu mengasah keahlian yang dimiliki perempuan melalui program kerja, kegiatan yang melibatkan perempuan dengan begitu perempuan dapat mengekspresikan keahlian 
mereka melalui ruang kolaborasi/kelompok sehingga mengantarkan perempuan menjadi perempuan yang mandiri dan berkualitas.

Selain itu peneliti juga mewawancarai seorang informan dapat disimpulkan bahwa dengan memotivasi perempun dan bertukar pikiran untuk memunculkan pemikiran baru dan ide baru agar ada inisiatif untuk mengembangkan kemampuan perempuan agar lebih berkualitas dan lebih mandiri. Berikut wawancara dengan Tp-pkk. Selaras dengan apa yang disampaikan oleh informan lainnya bahwa sudah ada itikad yang dilakukan oleh Tp-Pkk untuk memotivasi perempuan namun hanya sebagian yang mau mendengar ada juga yang kurang merespon. Upaya yang kemudian dilakukan kedepannya adalah lebih sering melakukan kegiatan yang dapat mengembangkan kapasitas diri mereka untuk meningkatkan minat mereka dalam pengembangan keahlian yang dimiliki.

\section{Peningkatan Kesadaran dan Pelatihan Kemampuan}

Stephen R. Covey (2002) Peningkatan kesadaran adalah sebuah landasan kokoh yaitu sebuah prinsip yang terbentuk didalam diri individu sehingga dapat merubah sudut pandang terhadap sesuatu, melalui peningkatan kesadaran diharapkan mampu mendorong individu untuk berubah. Pelatihan kemampuan adalah upayamendorong kaum perempuan untuk dapat meningkatkan skill sebagai bekal untuk berkontribusi terhadap pembangunan. Tujuan pelatihan kemampuan sebagai pengembangan kerja diarahkan untuk membekali, meningkatkan kompetensi kerja guna meningkatkan kemampuan, produktivitas dan kesejahteraan.

Adapun tujuannya sebagai berikut;

1. Memperbaiki pemahaman, meningkatkan kinerja yang efektif meningkatkanprogram pelatihan dan pengembangan yang sehat dan berfaedah.

2. Memutahirkan keahlian sejalan dengan teknologi melalui pelatihan, melalui pelatiahan, melatih individu agar dapat mwngaplikasikan teknologi baru secara Efektif.

3. Memutahirkan keahlian sejalan dengan kemajuan teknologi. Mengorientasikan individu terhadap organisasi dan bekerja secara benar.

Seiring dengan gagasan Simamora di atas peneliti mewawancarai seorang narasumber yang terlibatlangsung dalam tim penggerak pembinaan kesejahteraan keluarga tentang pemeberdayaan perempuan dalam lingkup masyarakat luas. Hasil wawancara menunjukkan bahwa sudut pandang perempuan tentang peningkatan kesadaran dan kemampuan harus terus digali sehingga perempuan juga berdaya dan miliki kemampuan. SDM merupakan unsur utama dalam menetukan keberhasilan karena merupakan penggerak untuk menentukan langkah apa yang akan dilakukan agar dapat berdaya dan berhasil sehingga upaya yang harus dilakukan adalah memberikan pemahaman. Berkaitan dengan hal itu hasil berikut pemaparan salah satu masyarakat bahwa pelatihan harus menjadi pembelajaran yang mengarahkan perempuan untuk lebih baik. Terkait dengan hal itu pemerintah daerah melalui kepala desa atau organisasi dalam lingkup desa (karang taruna, dll) menitisentralkan pada bagaimana cara memfasilitasi perempuan untuk 
melaksanakan kegiatannya dan menyediakan pelatihan bagi kaum perempuan agar perempunyai inovatif dan membawa perempuankearah yang lebih baik dan lebih maju.

\section{Pembangunan dan Pengembangan Jaringan}

Teori dan indikator pembangunan sebagai suatu perrumuskan melalui kebijakan dalam banyak hal membuktikan keberhasilannya terhadap pembangunan selain itu hasil-hasil pembangunan dapat dinikmati oleh seluruh masyarakat secara adil. Perempuan pada dasarnya adalah bagian dari sosial masyarakat yang memiliki hak dan peran yang sama dalam proses pembangunan sebagaimana yang disampaikandiatas bahwa keberhasilan pemberdayaan perempuan dapat dilihat dari keberdayaan perempuan dalam kaitannya dengan peran mereka dalam proses pembangunan sehinggga uapaya yang terus dilakukan adalah memberi pemahaman perempuan agar memanfaatkan setiap potensi yang dimiliki sehingga mendapat tempat untuk berkontribusi terhadap pembangunan seperti halnya laki-laki. Sejalan dengan hal itu salah satu informan memberikan masukan yaitu dapat dilihat bahwa dari dinas pemberdayaan perempuan sudah melakukan beberapa metode strategi untuk mengembangkan skill perempuan di Kota Sungai Penuh melalui pengembangan/perluasan jaringan untuk mendukung pendapatan dan sebagai solusi jitu untuk meningkatkan pembangunan melalui pendapatan daaerah sehingga perempuan dibekali keterampilan mereka.

Adapun yang disampaikan oleh informan di atas berkaitan dengan apa yang disampaikan oleh informan sebelumnya bahwa masih ada beberapa perempuan di Kota Sungai Penuh belum sepenuhnya berkembang karena diakibatkan oleh kurangnya akses luar derah yang bisa diajak bekerja, sama hal demikian menjadi salah satu faktor sehingga kurang berkembang beberapa usaha perempuan di Kota Sungai Penuh.

\section{B. Faktor Pendukung dan Faktor Penghambat Strategi Pemberdayaan Perempuan \\ a) Faktor Pendukung}

Pada pelaksanaan strategi pemberdayaan perempuan terdapat beberapa hal yang dapat membantu berjalannya program yang dilaksanakan. Rencana Pembangunan Jangka Menengah Daerah (RPJMD) Kota Sungai Penuh yang memuat program, kebijakan yang disahkan oleh Wali Kota Sungai Penuh diharapkan semua pihak ikut serta berpartisipasi dalam perumusan kebijakan Strategi Pemberdayaan Perempuan. Adapun beberapa hal di bawah ini yang membantu berjalannya pelaksanaan strategi pemberdayaan perempuan dan perlindungan anak yaitu;

\section{1) Melakukan Sosialisasi}

Pendekatan Sosialisasi tentang strategi pemberdayaan perempuan perlu dilaksanakan sebagai upaya mendorong kesadaran perempuan untuk lebih baik dan lebih maju. Aspek penting menyangkut strategi sosialisasi ini adalah pengembangan sumber daya yang berjangka panjang, berkesinambungan dan terciptanya kesejahteraan. Sosialisasi pada dasarnya sosialisai berkaitan dengan bagaimana meningkatkan pemahaman individu terhadap sesuatu yang baru. Sosialisasi sebagai suatu proses penanaman, transfer kebiasaan atau nilai dan aturan dari satu generasi ke generasi-generasi lainnya dalam sebuah kelompok dan 
masyarakat. pada proses sosialisasi di ajarkan peran-peran yang dapat dilakukan oleh kelompok dan individu. Sesuai dengan apa yang siampaikan oleh informan dapat disimpulkan bahwa sosialisasi dilakukan setiap bulan sosialisai bertujuan untuk merubah cara pandang perempuan agar lebih baik dan lebih produktif. Melalui sosialisasi diharapkan dapat merubah minset berpikir perempuan ke arah yang lebih baik sebab keberhasilan perempuan dalam perannya dimasyarakat merupakan tujuan dari pemberdayaan perempuan, sebagaimana yang disampaikan oleh informan yang lain, dari hasil wawancara dapat disimpulkan bahwa keinginan masyarakat agar sosialiasi dilakukan jangan hanya sekali sebulan dan harus ada tindak lajnut setelahnya. Tujuannya untuk menidak lanjut, dan mengevaluasi dari sosialisaisi sebelumnya agar ada perubahan yang dapat dirasakan oleh perempuan sehinggakedepannya harapan mereka dapat diwujudkan melalui kesadaran dan pemahaman yang lebih baik.

\section{2) Partisipasi Perempuan}

Hikmat (2001) konsep pemberdayaan terhadap wacana pembangunan masyarakat selalu di hubungkan dengan konsep partisipasi, mandiri, jaringan kerja, dan keadilan. Satu diantara prinsip tersebut merupakan prinsip partisipatif. Dalam prinsip ini ditekankan bahwa semua lapisan masyarakat baik laki-laki dan perempuant terlibat secara aktif dalam setiap proses pembangunan.

Melalui program pembangunan yang mengarah pada partisipatif tersebut diharapkan semua elemen dalam masyarakat dapat secara aktif ikut serta bersamasama berpartisipasi dengan cara mencurahkan pemikiran dan sumber daya yang dimiliki guna memenuhi kebutuhannya sendiri. Dari uraian di atas menunjukkan bahawa pelaksanaan dari proses strategi pemberdayaan perempuan dilakukan untuk meningkatkan kualitas perempuan di Kota Sungai Penuh, melalui kegiatan yang dilakukan menjadi harapan dinas pemberdayaan perempuan agar supaya perempua lebih aktif berperan di masyarakat. Partisipasi perempuan merupakan penopang keberhasilan dari tujuan yang akan di capai, melalui partisipasi perempuan diharapkan dapat lebih meningkatkan potensi yang dimiliki, selanjutnya menurut salah satu masyarakat. Sesuai dengan apa yang disampaikan oleh informan dapat disimpulkan bahwa sudah ada kesadaran perempuan untuk ikut dalam kegiatan yang dilaksanakan hanya saja mereka tidak bergabung dalam kelompok perempuan.

\section{3) Kerja Sama Lintas Sektor}

Sebagian dari masalah perempuan adalah merupakan masalah yang tidak dapat terlepas dari berbagai kebijakan dari sektor lain sehingga upaya ini harus sacarastrategis ikut serta melibatkan sektor-sektor terkait. Isu utama tersebut adalah bagaimana upaya peningkatkan kerjasama yang baik dengan lintas sektor sehingga dapat lebih efektif dan lebih efisien karena kerjasama dari berbagai lintas sektor dalam proses kegiatan pembangunan selama ini banyak yang berhasil, termasuk program yang berkaitan dengan strategi pemberdayaan perempuan disetiap daerah. Terkait dengan hal itu keterlibatan lembaga-lembaga dan LSM sertaantusiasmenya dapat menjadi power sehingga kedepannya ada perubahan yang dapat dirasakan oleh perempuan dan jauh dari ketertinggalan, terhindar dari kekerasandalam rumah tangga, pergaulan bebas sehingga perempuan mendapatkan tempat dan peran dalam semua bidang kehidupan. 


\section{b. Faktor Penghambat}

Faktor penghambat adalah hal-hal yang menghambat proses strategi pemberdayaan perempuan, setiap metode yang digunakan tentunya ada pendukung dan penghambatnya. Adapun beberapa yang faktor yang menghambat strategi pemberdayaan perempuan di Dinas pemberdayaan perempuan dan perlindungaan anak di Kota Sungai Penuh yaitu;

\section{1) Kurangnya kesadaran perempuan}

Tingkat kesadaran perempuan akan menimbulkan partisipasi untuk ikut mengelola dan terlibat. Kesadaran akan pentingnya untuk membawa diri atau kelompok ikut serta merupakan kemampuan untuk bertindak dalam keberhasilan keterpaduan yang teratur untuk menanggapi kondisi yang terjadi dilingkungan sehingga ada kesadaran atau keinginan bertindak sesuai dengan logika dari yang dikandung oleh kondisi lingkungan tersebut Adjid (1985).

Dari uraian di atas dapat disimpulkan bahwa kesadaran perempuan untuk ikut turut serta dalam kegiatan yang dilaksanakan masih kurang dimana secara umum penentu keberhasilan yang ditargetkan jauh dibawah rata-rata rasionalnya sehingga ditemukan salah satu agenda permasalahanny adalah indeks kualitas sumber daya yang rendah berakibat output yang ingin dicapai.

Terdapat kurangnya pemahaman perempuan tentang tujuan peningkatan kapasitas diri mereka sebagaimana ada beberapa perempuan beranggapan bahwa karena tidak berpendidikan mereka tidak layak sehingga mereka malas terlibat dan hanya tahu tentang bertani sehingga menjadi penghambat mereka untuk lebih maju dan berkembang.

\section{2) Kurangnya Sarana dan Prasarana}

Pada dasarnya sarana dan prasarana adalah segala sesuatu yang menunjang terselenggaranya suatu proses pelaksanaan pengelolaan sarana dan prasarana merupakan suatu kegiatan yang sangat penting, karena keberadaannya akan sangat mempengaruhi tujuan yang akan dicapai. Untuk itu, sarana dan prasarana merupakan hal yang sangat mendukung dan harus sangat di perhatikan karena mempunyai pengaruh yang sangat besar.

Menurut Djoyowirono (2005) Secara rinci ada beberapa tujuannya adalah sebagai berikut:

1. Untuk menyesuaikan apa saja fasilitas yang dibutuhkan sebagaipendukung terlaksananya tujuan.

2. Untuk mengupayakan tujuan dan pemakaian sarana dan prasarana secara tepat dan efisien.

3. Mengupayakan cara pemeliharaan sarana dan prasarana yang dibutuhkan sehingga keberadaannya selalu dalam kondisi baik dan siap pakai

Kendala yang dihadapi kaum perempuan adalah kurangnya sarana dan prasarana, mereka ingin mengembangkan minat mereka tapi ada banyak hal yang belum sepenuhnya memadai termasuk diantaranya sumber daya, sarana dan prasaran.dapat disimpulkan, bahwa pemberdayaan dan keterampilan untuk perempuan belum sepenuhnya merata dilihat dari bebrapa hal yaitu masih ada desa yang belum dijangkau dan diberdayakan kaum perempuannya hal itu menjadi faktor penghambat kemajuan dan kesejahteraannya.

\section{3) Beban dan Peran Ganda}


Beban dan peran ganda perempuan adalah tugas rangkap yang dijalani seorang seorang perempuan (lebih dari satu peran) yaitu sebagai ibu rumah tangga, dan sebagai orang tua anak, sebagai istri dari suami dan peran sebagai pekerja yang mencari nafkah membantu suaminya dalam bidang ekonomi keluarga. Beban ganda diukur sesuai dengan total waktu yang gunakan dan dilakukan perempuan menikah yang bekerja untuk mengerjakan pekerjaan domestik dan public. Sebagaimana penuturan informan bahwa kendala yang yang dihadapi adalah waktu dan kesempatan terlebih mereka banyak menghabiskan waktumengurus rumah tangga dan pekerjaan yang lain sehingga beban mereka serta waktu yang ada kadang menjadi faktor penghambat untuk ikut serta dalam setiap kegiatan pemberdayaan yang dilaksanakan. Dari pernyataan informan dapat disimpulkan bahwa kendala yang dihadapi oleh perempuan adalah waktu dan pekerjaan yang selain sebagai ibu rumah tangga juga sebagai seorang pengajar sehingga waktu untuk ikut terlibat kurang atau bahkan tidak ada.

\section{KESIMPULAN}

Berdasarkan penelitian yang di lakukan melalui wawancara oleh penulis dengan judul "Strategi Pemberdayaan Perempuan di Dinas Pemberdayaan Perempuan dan Perlindungan Anak Kota Sungai Penuh", beberapa hal yang menjadi kesimpulan dari hasil penelitian yaitu:

1. Pemberdayaan perempuan di Kota Sungai Penuh belum bisa dikatakan maksimal dan berhasil dilihat dari angka kekerasan perempuan yang terus mengalami peningkatan diakibatkan karena faktor didalam dan diluar lingkungan keluarga dan masyarakat, serta meningkatnya angka kekerasan perempuan yang tergolong jauh dari kata sejahtera. Hal ini menjadi salah satu penghambat keberhasilan kaum perempuan sebagaimana masih banyak perempuan di Kota Sungai Penuh yang belum berdaya.

2. Strategi pemberdayaan perempuan yang dilakukan dengan cara sosialisasi, memberikan pemahaman dengan cara pembentukan kesadaran secara menyeluruhbelum merata dimasyarakat, serta sarana dan prasarana yang tidak merata dan memadai dan bahkan tidak kena sasaran terhadap kelompok perempuan sehingga menghambat kegiatan yang menunjang keberhasilan perempuan sebagaimana sangat berpengaruh pada keberhasilan kaum perempuan di Kota Sungai Penuh

3. Kurangnya kesadaran perempuan terhadap pelaksanaan dan kebijakan yang ada berdampak besar pada peran perempuan yang tergolong kecil serta berakibat padamarginalisasi, dan kekerasan.

4. Kegiatan pelaksanaan program yang dilaksanakan oleh dinas pemberdyaan perempuan dan perlindungan anak di Kota Sungai Penuh sudah baik akan tetapi dilihat dari kondisi kesadaran perempuan serta sarana dan prasarana yang belum sepenuhnya mendukung sehingga menjadi penghambat keberhasilannya.

\section{Saran-saran}

Dari kesimpulan yang penulis tuangkan di atas tentang Strategi PemberdayaanPerempuan di Dinas Pemberdayaan Perempuan dan Perlindungan Anak Kota Sungai Penuh" adapun saran-saran penulis sebagai berikut

1. Mengenai sosialisasi yang dilaksanakan oleh Dinas Pemberdayaan 
Perempuan dan Perlindungan Anak Kota Sungai Penuh mengenai strategi pemberdayaan perempuan sebaiknya proses yang di laksanakan dilakukan secara bertahap dan bekesinambungan, kemudian menjangkau semua daerah khususnya daerah yang banyak terjadi kasus KDRT, pelecehan, penganiayaan terhadap perempuan, sehingga dapat merubah kondisi yang terjadi.

2. Pembinaan terhadap perempuan harus terus di tingkatkan termasuk bimbingan konseling dan pengembangan kelompok usaha dengan begitu perempuan dapat memanfaatkan potensi dan mengembangkan minat dan keahlian mereka melalui wirausaha dengan begitu perempuan lebih mandiri dan bisa mencukupi kebutuhanEkonominya.

3. Dari Pihak pemberdayaan perempuan, pemerintah dan masyarakat harus turut andil dalam proses pelaksanaan agar supaya semua berjalan dan terarah sesuai tujuan yang ingin dicapai. Selain itu kerja sama yang baik dari semua pihak merupkan langkah yang baik agar tercapai apa yang di harapkan.

4. Memeratakan keterlibatan perempuan, mengajak perempuan lebih produktif dan inovatif agar perempuan memilki kualitas diri dengan begitu dapat meminimalisir/menghilangkan subordinasi, stereotipe, marginalisasi dan kekerasan baik dalam lingkup rumah tangga maupun di masyarakat.

\section{UCAPAN TERIMA KASIH}

Dalam kesempatan ini izin kan penulis mengucapkan terimakasih kepada kepada unsur pimpinan STIA NUSA Sungai Penuh yang telah mendukung penulis dalam pelaksanaan penelitian ini baik dukungan secara moril maupun materil. Ucapan terimakasih juga kami sampaikan kepada Ketua Lembaga Penelitian dan Pengabdian Masyarakat (LPPM) STIANUSA Sungai Penuh beserta seluruh Tim Editor yang telah bersedia untuk menerbitkan naskah artikel yang dimuat pada adisi ini.

\section{A. Buku}

\section{DAFTAR PUSTAKA}

Asang, Sulaiman, 2012. Membangun Sumber Daya Berkualitas. Makassar: BrlianInternasional Surabaya

Astuti, Marwanti.2002. Gender dan Diskriminasi Perempuan. Bumi aksara. Bandung Bungin, Burhan, 2001. Metode Penelitian Kualitatif. Surabaya: Rajawali Pers.

Bachri Bachtiar S. 2010. Meyakinkan Validitas Data Melalui Triangulasi pada Penelitian Kualitatif. Universitas Negri Surabaya. Surabaya.

Basuki Johanes, 2013. Budaya Pelayanan Publik. Jakarta: Media Pustaka.

David, 2011. Membangun Sumber daya Manusia Berkualitas. Brilian InternasionalSurabaya.

Elson, 1991. Indikator Pelaksanaan Strategi Pemberdayaan Perempuan.diakses dariwww.blogspluscom?/-indikator-pemberdayaan-perempuan.com

Lewis Artur, W. 1885. Perencanaan Pembangunan. Jakarta

Suharto Edi, 2000. Metode Partisipatoris dan Upaya Pemberdayaan. Jakarta: Yayasan Obor Indonesia. 
Jurnal Perempuan untuk Politik: Panduan Tentang Partisipasi Perempuan dalam Politik dan pembangunan, 2006:11-115.

Havidz Aima, dkk, 2015. Enterepreneurship dan peluang usaha. Jakarta. Hasibun, 2003. Manajemen Sumber Daya Manusia, Bumi Aksara, Jakarta. Moleong, Lexy J. 2007. Metodologi Penelitian Kualitatif. Bandung: Remaja Rosdakarya.

Muljana, 1995. Perencanaan Pembangunan Nasional, Jakarta: Universitas Indonsian.Nugroho Riant. 2012. Public Policy. PT Elex Media Komputindo: Gramedia. Jakarta Nugroho,Riant. 2008. Gender dan Adminsitrasi Publik. Pustaka Pelajar. Yogyakarta.

Pratama, Crisvi, 2013. Pemberdayaan Perempuan Dalam Pembangunan, Vo. 1 No. 1-2 Januari-April 2018:14-16http://bogorplus.com/index.php/item/6963memberdayaan-kaum-perempuan-melalui-pembinaan-dan-pengembanganorganisasi-perempuan.

Ruslan, Murniati, 2010. Pemberdayaan Perempuan Berbasis Gender: jurnal Pemberdayaan Perempuan: Konsep dan Strategi 92 Musawa, Vol. 2, No. 1, Januari 2018:79-96.

Siagian, Sondang P. 2009. Manajemen Sumber Daya Manusia. Cetakan Ketujuh belas. Jakarta: Bumi Aksara

Salusu J, 2006. Manajemen Strategi. Jakarta: Pustaka Pelajar, In Media.

Sugihastuti, 2007. Gender dan Inforioritas Perempuan: Yogyakarta: Pustaka

Pelajar.Sugiyono. 2003. Metode Penelitian Bisnis. Edisi1, Bandung: Alfabet.

Siagian, 2004. Manajemen Strategi Organisasi. Yokyakarta: Pusaka pelajar.

Suyono, 2001. Kualitas Pemberdayaan Perempuan di akses dari https://kalteng.go.id/INDO/Pemberdayaan_Perempun/ pada tanggal 09 Maret 2018.

Setyasih. 1998. Partisipasi Perempuan Terhadap Pembangunan Daerah. jurnal ilmu administrasi publik. Vol. 14. No. 3 (Januari)

UNDP, 2001, Konsep Membangun Sumber Daya Manusia Berkualitas. Dalam asang sulaiman, Makassar: Brlian Internasional.

Fakih, Mansour, 1996. Analisis Gender dalam Transformasi Soasial. Yogyakarta: Pustaka Pelajar.

Wahib, 2012. Langkah langkah yang dilakukan dalam pemberdayaan perempuan. 